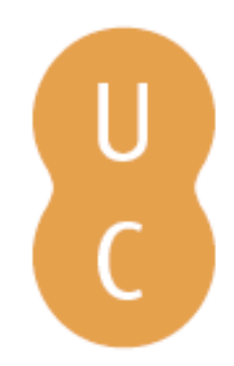

\title{
nommalina
}

\section{The influences of Darwin's thought and Darwinism in portuguese psychiatry}

Autor(es): $\quad$ Pereira, José Morgado

Publicado por: Imprensa da Universidade de Coimbra

URL

persistente: $\quad$ URI:http://hdl.handle.net/10316.2/31300

DOI: $\quad$ DOI:http://dx.doi.org/10.14195/978-989-26-0342-1_24

Accessed : $\quad$ 26-Apr-2023 13:28:37

A navegação consulta e descarregamento dos títulos inseridos nas Bibliotecas Digitais UC Digitalis, UC Pombalina e UC Impactum, pressupõem a aceitação plena e sem reservas dos Termos e Condições de Uso destas Bibliotecas Digitais, disponíveis em https://digitalis.uc.pt/pt-pt/termos.

Conforme exposto nos referidos Termos e Condições de Uso, o descarregamento de títulos de acesso restrito requer uma licença válida de autorização devendo o utilizador aceder ao(s) documento(s) a partir de um endereço de IP da instituição detentora da supramencionada licença.

Ao utilizador é apenas permitido o descarregamento para uso pessoal, pelo que o emprego do(s) título(s) descarregado(s) para outro fim, designadamente comercial, carece de autorização do respetivo autor ou editor da obra.

Na medida em que todas as obras da UC Digitalis se encontram protegidas pelo Código do Direito de Autor e Direitos Conexos e demais legislação aplicável, toda a cópia, parcial ou total, deste documento, nos casos em que é legalmente admitida, deverá conter ou fazer-se acompanhar por este aviso. 
Ana Leonar Pereira João Rui Pita

Pedro Ricarda Fonseca (eds.)
Darwin,

Evalution,

Evolutionisms

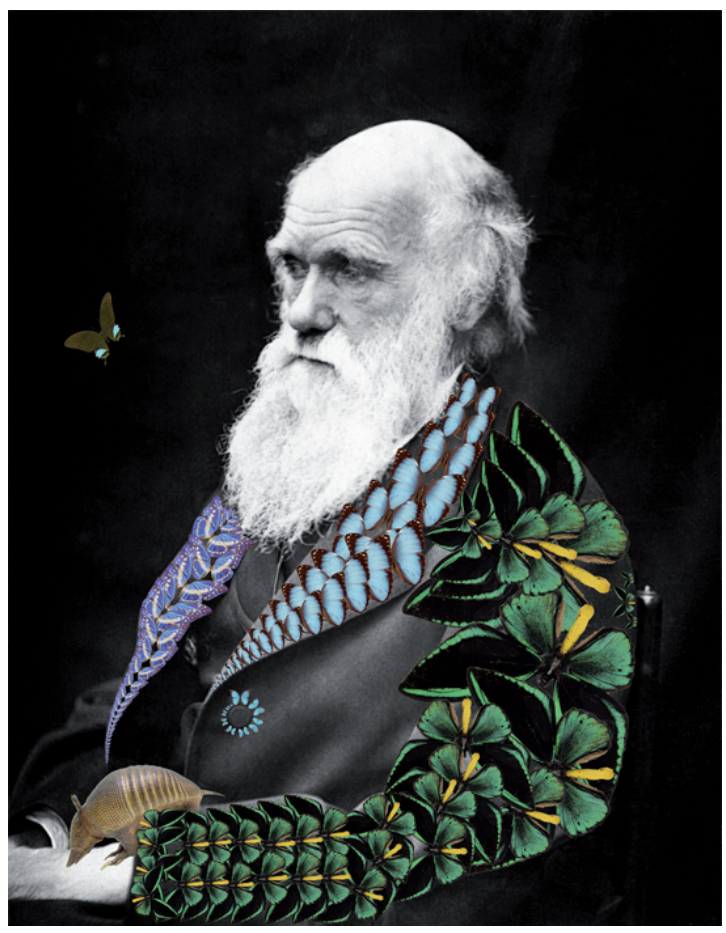




\section{The Influences of Darwin's Thought and Darwinism in Portuguese Psychiatry}

The publication of The Origin of Species by Charles Darwin in 1859 triggered a profound scientific and cultural revolution. The image of man and his place in nature became different to that which had been established by the Sacred Texts. Man stopped considering himself as a being separate from the rest of nature, to start considering himself as simply a species among others, from the order of primates and the class of mammals, influenced by the same natural causes which determine them. Thus, a line of thought, still present today, was initiated, explaining man and nature not by religious or metaphysical means, but resorting solely to one science: Biology.

Its influence on the most diverse domains and subjects was great, frequently questioning Theology and Religion, making it possible for "Man to enter the scope of Zoology" and enabling the "disassembling of Theology". Darwin's influence upon Herbert Spencer and Karl Marx was great and Biology became a key discipline. Physicians like Bombarda frequently defined themselves as biologists and physiologists and it is evident now that a retrospective analysis reveals a frequent "biologization" of social facts.

The first evolutionary psychologists understood that individual evolution should situate itself in a broader process of phylogenetic evolution. The German naturalist Ernst Haeckel popularized the fundamental biogenetic law, according to which ontogeny recapitulates phylogeny. Also, the onto-phylogenetic parallelism was transferred to the stages of psychological development. We know today that these hypothetical parallelisms taught us little about the more important processes which are produced in psychological development. However, despite the mistakes, these positions were considered progressive at the time because they introduced psychological evolution within a naturalistic framework - until then the reference points had been philosophical or religious ideas.

It did not take long for Darwinism to extend itself into an ideology - social Darwinism - which abusively applied to human society the concepts of "Struggle for life" and "Natural selection", aiming at the rationalisation of violence, misery and injustice, in an attempt to justify the social conditions which characterized the industrial society of the $19^{\text {th }}$ century.

Colonialism also tried to support itself on social Darwinism, through an ordinary usurpation of a scientific theory. Lombroso's publication of The Delinquent Man, in 1876, is significant: the Italian criminologist presented a personal interpretation of the Theory of Darwinian Evolution to prove the inferiority of criminals in relation to 
"honest people", women in relation to men, coloured people in relation to Caucasians, reinforcing the prevailing policies of sexual and racial hierarchy.

The immediate repercussion of Darwin's theory in Psychology and Psychiatry varied. There were clear influences upon William James and James Marc Baldwin and upon the philosopher and teacher John Dewey as well. In the scope of neurology it is the work of Hughlings Jackson which most reflects the influence of evolutionary theories. His interpretive model of neurological symptoms as a phylogenetic hierarchy of disintegration of the Nervous System was a very advanced global concept for the time and had further repercussions on psychiatric thought, mainly upon Henri Ey. Another less direct influence, but also evident, was Sigmund Freud's work based on his theoretical model of Mind in the Theory of Instincts, considering survival instincts, on the one hand, and sexual instincts, on the other.

However, it was the English philosopher Herbert Spencer who, in the $19^{\text {th }}$ century, most strived to erect an evolutionary Psychology, popularising the term "survival of the fittest" and introducing evolutionary matters into sociologic and philosophic theories.

Indeed, social Darwinism is far from Darwin's positions and, according to some authors, should be called "social Lamarckism", because it is centered on the hypothesis of the transmission of acquired characters.

These theories ended up wearing down Darwinist theories among sociologists and the practitioners of human sciences, a reality that extended itself almost until the present.

The influences and the testimonies of the influence of Darwin's work have been the subject of various studies. In this essay, and regarding Portuguese Psychiatry, we mention the importance of the notion of Degeneration, in line with the French psychiatrists Morel and Magnan, which would have a great influence throughout many countries, including Portugal.

The so-called Criminal Anthropology also had an enormous importance in Law, Psychiatry, Criminology, and Legal Medicine.

If we check Patrick Tort's monumental dictionary of Darwinism and evolution, we find the names of Morel and Magnan in France, Maudsley in England, Kraft-Ebing in Germany, Lombroso in Italy, who powerfully influenced our alienists of the end of the $19^{\text {th }}$ century and the beginning of the $20^{\text {th }}$ century. The idea of Degeneration became a broadened basic concept, but it needs to be disclosed, because its meaning changed from the $18^{\text {th }}$ century to the $19^{\text {th }}$ century, only gaining an almost derogatory meaning towards the end of the $19^{\text {th }}$ century.

The problem is that it is not easy to rigorously limit the Darwin/Darwinism or Science/Ideology dichotomy. The physician and politician Brito Camacho writes that "the principle of the struggle for life collected from Darwin's observation and applied by him to all biological beings extends to social aggregates and dominates the very complex phenomenability of the world of ideas and emotions".

In 1878, Júlio de Matos, in a letter to Teófilo Braga, mentions that he is writing an essay on the Evolution of Biology in which "I aim to demonstrate that this hypothesis, despite the opposing resistance at first by Auguste Comte, should be embraced by Positive Philosophy". He further adds that he also attempts to justify the criticism which Comte opposed to Lamarck, because for the latter "there was an intrinsic force, predetermined and pre-established, an initial impulse viewed as the most important factor in the explanation of species transformism". And concludes by stating, "this is 
pure Metaphysics". The question changed form, adds Júlio de Matos, "after the Works of Darwin, Wallace and Haeckel, and I believe that it is impossible today for a positivist not to accept transformism as a legitimate hypothesis. This is the basis of my work". The essay "Ensaio sobre a evolução em Biologia" (Essay on evolution in Biology) appears published in the journal "O Positivismo" in three parts. In it he emphasizes how illegitimate it would be for a contemporary positivist to, despising the achievements of modern science, which are entirely favourable to transformism, insisted in opposing this fertile biological conception; and, in the second part writes: "natural selection is an unconscious fact, the blind product, nothing else, of physical-biological conditions of our planet. The principle does not represent anything more, and it is with the condition that it does not exceed these limits in which Science accepts it and thus, Positive Philosophy".

In volume 4 of "O Positivismo" it was also Júlio de Matos who signed Darwin's obituary, giving public testimony "of the sadness that the loss of that beautiful spirit for which despite the disagreements in many of his philosophical views, attracted our profound sympathy". In 1880, Júlio de Matos publishes his first volume of "Historia Natural Ilustrada" (Illustrated Natural History), which will have a total of 6 volumes. The volume seems written by a naturalist and, as the author indicates in the preface, consists of a rational compilation of everything which has been written on the subject by sages like Brehm, Buffon, Figuier, Milne Edwards and is destined to fill an urgent need: the teaching of natural matters. The author further adds: "from the new works of the transformist school appear principles and thesis which are as of now, undeniable acquisitions of science. We will give them the exposure they deserve as positive and confirmed doctrines. In this case, these principles of struggle for life and natural selection are justly considered the safest and richest of modern natural history". Further ahead, and regarding the question of the origin of man, he explains that the evolutionary school invoked the principles of the struggle for existence, of natural selection, of adaptation, of heredity, quoting Haeckel, Quatrefages, Darwin and Spencer.

Júlio de Matos will remain faithful to his program, especially to the defense of the integration of Darwinian evolutionary principles within Positive Philosophy. Gil Cremades highlights the relationship of Positivism with Republicanism in Spain and Portugal, considering that to support that political project, the reception of Positivism will adapt Comte, admit Darwin's dynamic and reiterate the organicism of Herbert Spencer and adding, curiously, that this process was more conscientious in Portugal, quoting the journal "O Positivismo" and the works of Teófilo Braga and Manuel Emídio Garcia.

The positions of Miguel Bombarda are different. In 1891, in "Traços de Fisiologia Geral e de Anatomia dos Tecidos" he considers that "Darwin's hypothesis is the one that best agrees with the great generality of phenomenons of heredity and its numerous particular laws", but also believes that "the heritage of acquired qualities, which are undeniable, is entirely understandable in the Darwinian hypothesis.". Although valuing the work of Darwin, Bombarda criticizes natural selection, stating that "Lamarckian ideas dominate Science in all of the transformist doctrine" in 1909.

In 1908, Bombarda wrote in the preface of Ladislau Batalha's book "O Negativismo" (The Negativism) that he disagreed with the author when he tried to demonstrate that the supreme lie is altruism and that the fight of egoisms is the condition itself of progress and civilization. For Bombarda, on the contrary, "in all of nature, the cooperation factor has been the superior source of adaptation and evolution" and adds "Darwinian selection, 
with its heartbreaking and impotent struggle for existence, has had its time" and yet "with prince Kropotkin I would even say, for man's moral progress, more precisely, in a larger extent of mutual help resides the best guaranty of a more upright evolution of our species". We know that the anarquist Kropotkine, regarding the mechanism of organism transformation, supported the decisive importance of the direct influence of the environment over the living being. In his memoirs, he criticizes the conclusions to which the formula "struggle for life" dragged most of Darwin's disciples, adding that "nowadays infamy is not practiced in civilised society or in the relationships of white people with so-called "inferior" races, or the strong and the weak, that do not find in that formula an excuse". For him, "mutual help" (the expression Bombarda also uses) is as much a law of nature as "reciprocal struggle", but for the progressive evolution of a species, the first is more important than the second.

In an essay on Loucura Penitenciaria (Penitentiary Insanity), in 1897, Bombarda tries to show the pernicious action of the cellular comfinement on the psychic life of prisoners and accepts the existence of a penitentiary psychosis, establishing a small controversy with Júlio de Matos. Despite his biologist orientation, Bombarda valued the social environment, while Júlio de Matos "tended to view the social question as of bio-anthropological nature" (A.L.Pereira). The differences in political orientation occurring from that divergence of opinion are noticeable: a democracy with socializing tendencies and the primacy of the environment for Bombarda; and the anti-socialist republicanism of Julio de Matos, which appears linked to his defense of Darwinism and evolutionism, and their integration within Positive Philosophy.

Overcoming these conceptions brings us closer to contemporary Psychiatry, implying a distancing from Biologism, understood by the overwhelming weight of Biology and heredity, perceived as an almost absolute determinism.

The interest in psychological life, after important psychoanalytical, phenomenological and human and social sciences contributions, will lead to a distancing, in some cases, of the biological bases of behaviour, which only returned decades later, based on new and distinct scientific principles.

\section{Bibliography}

BATALHA, Ladislau - O Negativismo, Lisboa, Parceria António Maria Pereira, 1908

BOMBARDA, Miguel - Traços de Fisiologia Geral e de Anatomia dos Tecidos, Lisboa, Letterpress of the General Academy of Sciences, 1891

BOMBARDA, Miguel - La Folie Penitentiaire in “Revista Portuguesa de Medicina e Cirurgia Práticas” n¹4, 1897

BOMBARDA, Miguel - Estudos Biológicos. A Consciência e o Livre Arbitrio., Lisboa, Parceria António Maria Pereira, 1898

CAMACHO, Brito - A reacção, Lisboa, Editora Luz Lda, 1932

CONRY, Yvette (Ed.) - De Darwin au Darwinisme: Science et Idéologie, Paris, Vrin, 1983

CREMADES, Gil - La Dimension Politica del Positivismo en España y Portugal in Actas II Congreso de la Sociedad Española de Historia de las Ciencias by Hormigón, Mariano (Ed.), 1984

FERRĀO, António - Teófilo Braga e o Positivismo em Portugal, Lisboa, Offprint of the Second Grade Bulletin of the Academy of Sciences of Lisboa, 1935 
KROPOTKINE, Pedro - Em volta duma vida. Memórias, Lisboa, Tipografia do Comércio, 1907

MATOS, Júlio de - Ensaio sobre a Evolução em Biologia, in "O Positivismo" vol. 1, Porto, 1878-1879

MATOS, Júlio de - História Natural Ilustrada, Porto, Livraria Universal, 6 volumes, 1880-1882

MATOS, Júlio de - Carlos Darwin, in "O Positivismo" vol. 4, Porto, 1882

PEREIRA, Ana Leonor - Darwin em Portugal (1865-1914), Coimbra, Almedina, 2001

TORT, Patrick - Dictionnaire du Darwinisme et de l'evolution, 3 volumes, Paris, Presses Universitaires de France (P.U.F.), 1996 